\title{
Weigh-in-motion at implementation risk sharing on performance-based contract in Indonesia national road
}

\author{
Hanie Teki Tjendani ${ }^{*}$, Nadjadji Anwar ${ }^{1}$, and I Putu Artama Wiguna ${ }^{1}$ \\ ${ }^{1}$ Department of Civil Engineering, Institut Teknologi Sepuluh Nopember, Surabaya, Indonesia
}

\begin{abstract}
The Government of Indonesia has implemented an integrated contract, performance-based contract (PBC) to preserve national roads since 2011. Comparing with conventional agreements that prioritize input and maintenance processes, $\mathrm{PBC}$ prioritizes the output and outcome of clear and measurable road performance. In the performance-based contracts are required WIM (weigh in motion) tools to monitor the overloading vehicles throughout national roads with PBC and should be provided by the contractor as stated in the contract. However, the installation of WIM tools with the high budget has not been beneficial for the contractor because not followed by punishment for the "overloading" vehicles. $\mathrm{PBC}$ is the risk sharing between government as road authority and the contractor as the private sector. So, in PBC practice not allowing any significant losses on either party. This study resulted in a performancebased contract simulator by combining WIM technology and dynamic system methods. If the government succeeds in stopping the overloading vehicle entering the road with $\mathrm{PBC}$ contract but the contractor still fails to meet the minimum performance, that is the own risk of the contractor and resulted in the imposition of a fine to the contractor as established in the PBC contract. .
\end{abstract}

\section{Introduction}

The problem of infrastructure in Indonesia is the premature deterioration of the national road. This problem is not only caused by overloading, high level of groundwater and side friction [1] but also can be due to human factors and the selection of contract management systems [2].

In general, the contract of construction and maintenance of national roads is still using "traditional-contract". There are three companies in one project involved, i.e., the planners, consultant, supervisory consultants, contractors and executed on a single year contract. Several months after the defect liability period has been completed, and there are signs of damage to the national road pavement. So, the road users cannot enjoy the trip that safety, comfort and minimize travel time. It can bring about to questions, speculations and the assumption that the deterioration of road is caused by inaccurate planning, implementation

*Corresponding author: hanie tekitjendani@yahoo.com 
of work that is not following the specification and method and the lack of accurate supervisory the field work. These cases cause the risk of road rehabilitation to become a burden on Directorate General Bina Marga as road authority in Indonesia (government). Whereas, the national road should be able to serve the traffic by the designed at the time of planning period and established in the planning contract. This condition can also due to the contractor action not based on the method specified in the contract. For example, in the compacting of flexible pavement required the number of track roller to be performed, if the contractor reduces the amount of predetermined compaction track, as well as the supervisory consultant, does not give any warning to the contractor so that national road pavement will be damage faster. And the incident proves that the risk that should be the burden of planners, supervisors, and contractors ultimately burden the road authority (government) because the government must make additional repairs to roads and improved to provide the best service to road users [3].

\section{Literature review}

Based on the problems described earlier, it can be said that the government's risk of maintaining national roads with conventional contracts is enormous, even should be borne the risk of service providers, planners, supervisors, and contractors. This is undoubtedly very inequitable. The risk should be taken by the party that caused the risk occurred. Also, the separation of design and maintenance in long-term maintenance contracts has been recognized as a limiting factor in adapting to life-cycle costs. Thus the widespread view that integration further enhances the success of a project becomes a driver for using integrated and innovative contracting practices [4]. Until now, highway agencies around the world have run into significant changes in road maintenance practices that were formerly from traditional contracts, beginning to change over to performance-based contracts or Performance-Based Contracts (PBC) this is an option for collaborative efforts with the private sector [5]. Regardless of the type of contract used, the construction project involves multiple stakeholders, long periods of time, open production systems, including interactions between internal and external environments, having unique issues, organizational and technological complexity that can lead to a number of risks [6]. Risk transferring to contractors on performance-based contracts aims to reduce total maintenance costs over the life cycle of the pavement by utilizing the efficiency of private sector management. The owner (government) makes payments when the contractor successfully meets or exceeds a minimum performance indicator therein defined clearly [7] enables sustainable road preservation management over the life of the service, resulting in long-term cost reduction and cost savings for the government [8].

Also, the government must monitor the performance of $\mathrm{PBC}$ to be more comprehensive and accurate in five key areas: service level effectiveness, cost efficiency, fast of response, safety procedures, and service quality to ensure comprehensiveness and reliability of the evaluation process [9]. In subsequent studies presents a methodology for estimating the chance of cost savings amount associated with implementing performance-based contracts for road maintenance operations. Using data on maintenance contracts from around the world, models were developed that could be used to compare several contract methods including variables such as contract duration, activity type, and contract size [5].

\subsection{Performance-based contract in Indonesia}

There are several methods of road operations in the world, namely: 1) Design-Bid-Build (DBB) or known as traditional or conventional methods, 2) Design-Build (DB), and 3) Construction Manager/General Contractor (CM/GC). DBB used for high-risk jobs. In the 
DB method, the contractor is entirely responsible for the design and construction. Implementation of the design and construction can run simultaneously. The selection of the above methods depends on several factors such as completion time, complexity and innovation, design difficulty level, risk assessment, cost, human resources, competition, and the contractor/ consultant capabilities [10].

Performance-Based Contract (PBC) road operations are one of the more complex forms of DB type road operations. In principle the difference in the $\mathrm{DBB} /$ traditional method with the DB as shown in Fig. 1. PBC is one form of road procurement system aimed at improving management and maintenance effectiveness in a way that the physical road condition has been established [7].

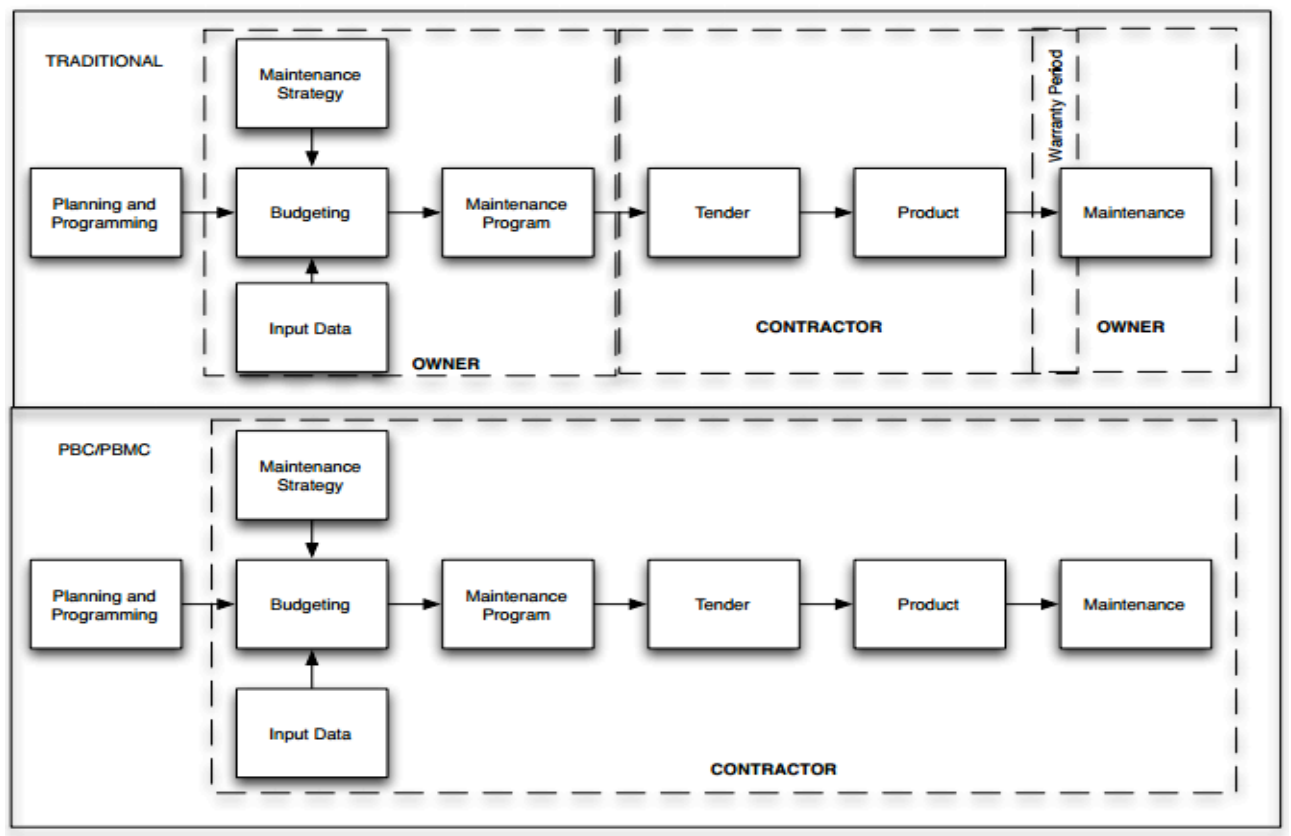

Fig. 1. Conventional and performance-based contract.

In Indonesia, a performance-based contract implemented beginning in 2011 in the form of a pilot project in Java island, i.e., on the 1) Ciasem-Pamanukan national road section done by contractor PT. Waskita Karya with contract period 2011-2014 and length of road $18.50 \mathrm{~km}, 2$ ) Demak-Trengguli road (PT Adhi Karya), contract period 2011-2014, length $7.68 \mathrm{~km}, 3$ ) Semarang-Bawen segment (PT Adhi Karya), contract period 2012-2018, length $22 \mathrm{~km}, 4)$ Bojonegoro-Padangan (PT Pembangunan Perumahan), contract period 20122018, length $11 \mathrm{~km}, 5$ ) Padangan-Ngawi (PT Hutama Karya) contract period 2012-2018, length $9.15 \mathrm{~km}$ while outside Java island is in 6) Central Kalimantan, the Sei HanyuTumbang Lahung road is done by PT Adhi Karya, $50.60 \mathrm{~km}$ and contract period 20132019. In the developing and developed countries that have implemented PBC can do cost saving for the government. In the first and second pilot project in Indonesia, projects have not been to prove cost savings, the condition improved on the third project of Semarang Bawen (PT Adhi Karya) with the cost saving of 17.90\%, Bojonegoro-Padangan (PT PP) with cost saving $9.09 \%$ and Padangan-Ngawi road (PT Hutama-Work) with cost saving $9.15 \%$. [10,11].

All national road pilot projects with performance-based contracts are undertaken by state-owned enterprises with the contract duration of four years and seven years. In 2015, the bidding had been held for a performance-based contract with a term of 10 years but 
experienced several failed bids. This is understandable since basically a performance-based contract is a risk response that requires the contractor to be responsible for all risks from planning, construction to operation and maintenance work. For contractors who are not experienced with $\mathrm{PBC}$ contracts, there are a lot of concerns, especially the main parameters that can determine the success of PBC implementation among others, existing data collection, deadline of bid submission, limited duration of design, not fully applied the principle of $\mathrm{PBC}$ and coordination among stakeholders. It is based on risk analysis to find the best practice in $\mathrm{PBC}$ contract implementation in Indonesia based on risk category at pre-bidding, bidding, design, build, operation and maintenance stage.

PBC is the risk sharing between the government and the contractor so that in its implementation there should not be any one of the disadvantaged but must be in a win-win situation to be in line with the government's goal in choosing this contract for public road maintenance. However, the implementation of this contract has not been beneficial for the contractor if not followed by punishment for the "overloading" vehicles.

\subsection{Technology as a support of successful PBC}

PBC is a form of contract innovation based on outcomes where road users are the primary focus in road operations. Some performance standards are closely related to the conditions that occur on the road. The rule of work to be achieved in PBC are 1) IRI (International Roughness Index), an effect on cost user operating, 2) no holes and control of cracks and rutting, impact on road safety and pavement performance 3) friction at least between vehicle tires and road surfaces affecting road safety, 4) the maximum amount of soil deposits or other obstructions that interfere with the drainage system affect road structures, 5) reflexes of markers and road signs affect the safety of road users [12].

Many things can happen at the time of the contractor to achieve the specified work standard. In the PBC is not allowed overloading but the government still has no rules to prohibit vehicle overloading through the road with $\mathrm{PBC}$ agreement. Even in the contract mentioned that the contractor must conduct procurement and installation of equipment to measure the weight of vehicle type WIM (weigh in motion). The repeated dynamic forces of heavy vehicle tires on highway pavements are the primary cause of pavement damage. These forces can be measured with weigh-in-motion (WIM) equipment and used to estimate the corresponding tire loads of static vehicles. The sum of the tire loads on all wheels of the same axle is called axle load (the portion of the gross vehicle weight supported by the axle), and the sum of all axle loads on the static vehicle is the total vehicle weight [13]. A WIM composition related to any suitable communication instrument can e connected to the primary monitoring server. Automatic data archiving software is necessary to resume the data from many faraway WIM posts to be prepared for any further processing. A central database can be built to link many WIMs to a server for the variety of monitoring and execution goals.

The fast measurement system is programmed to present estimations of the following parameters, namely axle space, single axle weights, gross vehicle weight, vehicle speed, the distance between vehicles, and the GPS synchronized time stamp for each vehicle measurement. The measurement composition should be environmentally covered, should have a wide operating temperature range and withstand condensation [14]. With the supportive technology required on PBCs, governments should be able to reduce overloading vehicles crossing roads with PBC contracts easily, but in reality, they have not yet realized. Vehicle overloading still freely through the street. WIM tools have become the obligations of contractors as stipulated in the contract of the employment agreement. So, if there is early damage due to vehicle overloading is also the responsibility of the contractor. $\mathrm{PBC}$ is risk sharing. It is not justified if the contractor suffers losses that should not be the 
own burden, but there must be compensation for contractors because the government failure can not stop overloading vehicles through roads with PBC contracts.
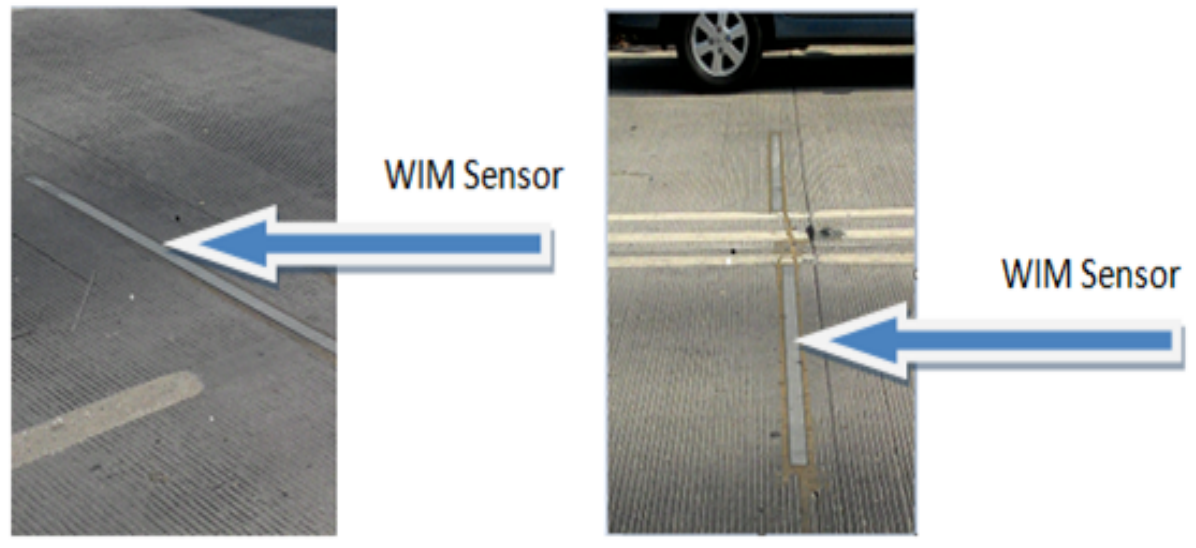

Fig. 2. Weigh in motion sensor at Bojonegora-Padangan Project.

\section{Research methodology}

In this research, a dynamic system simulation to find out how much the contractor losses due to vehicle overloading which through the road with PBC contract. The dynamic system was developed around the end of the year 60's to graduates from MIT (Massachusetts University of Technology), Jay Wright Forrester. Dynamic systems Made from computer models that can help us to learn useful functions [15].

Modeling dynamic systems is a robust approach to addressing complex problems, explains the causal relationship between inventory, flow, and feedback and development of construction projects, procurement of design, improvement of construction organization's performance, construction project construction, global systems, construction organization performance, competitive contractors and so on. [16] This dynamic system focuses on structures and behaviors consisting of interactions between variables and loop feedback. Relationships and interactions between variables in the caustic diagram. In a natural system, if in the face of the problem, then we will take a decision, take action without action after the result (open loop). In fact what happens is each of us finds a problem, we must act, after getting the result can not immediately keep silent but thinking of the question to come so next is an endless turn. Each action, each change is set in the feedback loops network. Feedback means to explain the situation when the output of an event in the past will affect the current or future events. The overloading condition in the implementation of PBC and the risks encountered by the contractor could be simulated in a dynamic system. The variables used in this study are divided into several sectors in the dynamic system, namely CESAL sector, road condition sector, road user sector, financial sector, pre-bidding sector, and average vehicle operating costs sector.

This study utilizes technology from WIM hardware, its input is a vehicle passing through the road, while the data output from WIM software is a vehicle overloading data that crosses the path. The data can use as input on Stella software with dynamic system method along with other data to produce a basic model on a performance-based contract simulator. At the time of design the traffic data used for planning, the calculation was taken from the result of the initial design calculation, CESAL (cumulative equivalent single axle load) score for 20 years is $79,000,000$ CESAL. 


\section{Results and discussion}

In this study, the basic model formation will produce a performance-based contract implementation simulator which can be used to determine the most optimal duration for each stage of work in the PBC, i.e., the step of design work, the phase of construction work and the maintenance service. The maintenance service has the most extended duration and potential risk in the PBC contract. With this simulator, we will know the most optimal time for the length of this maintenance service so that still in the condition does not harm either party that is contractor and government.
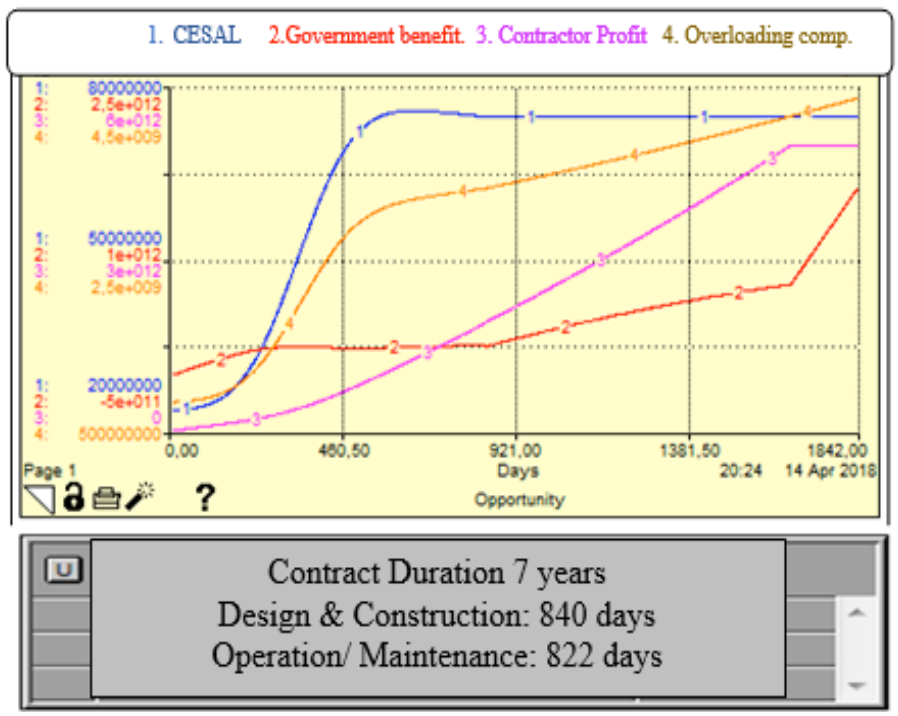

Fig. 3. Operation/maintenance simulation (duration -50\%).
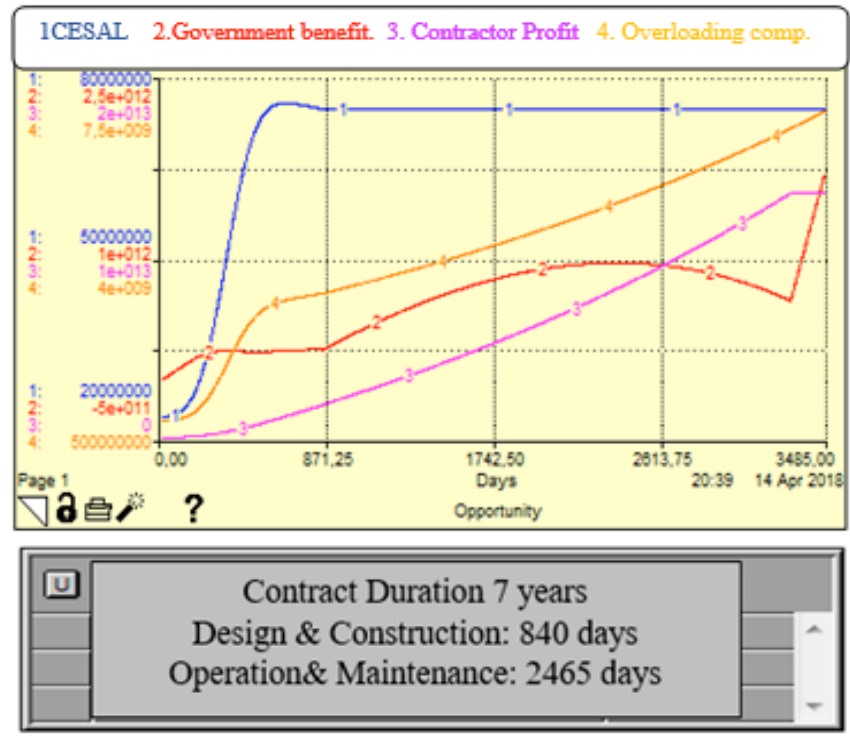

Fig. 4. Operation/maintenance simulation (duration $+50 \%$ ). 
This paper will show the amount of compensation that the government should give to the contractor if the vehicle overloading is still crossing the national road using the PBC contract. Because the $\mathrm{PBC}$ contract does not allow vehicle overloading through this road but in reality, this still happens.

In Fig. 3, a simulator for the duration of a 7 year contract, with a planning period and a construction period of 840 days while maintenance service conditioned at a $50 \%$ shorter duration than the duration in the contract on the Semarang-Bowen pilot project, i.e, 822 days (duration normal in contract $=1664$ days). It can see if desired at the time of maintenance service graph of CESAL value remains on condition according to contract hence vehicle overloading compensation which must be paid by the government to the contractor is IDR 4,500,000,000.

In Fig. 4, the planning and construction duration is 840 days but the maintenance service period is simulated 50\% longer than the contract maintenance period of 2465 days. In that duration, the compensation to be paid by the government to the contractor is IDR $7,500,000,000$.

\section{Conclusions}

This study resulted in a performance-based contract simulator by combining WIM technology and dynamic system methods. On the duration of a 7 year contract if the government can not stop vehicle overloading by road with a PBC contract then the government should provide overloading-compensation to the contractor amounting to IDR $4,500,000,000$ and IDR 7,500,000,000 for simulation duration of the maintenance service 822 days and 2465 days. If the government succeeds in stopping the overloading vehicle entering the road with PBC contract, but the contractor still fails to meet the minimum performance, that is the own risk of the contractor and resulted in the imposition of a fine to the contractor as established in the PBC contract.

\section{References}

1. R. Tamin, A. Tamin, P.F. Marzuki, Proc. Eng. 14 (2011)

2. H. Rahadian. www.pu.go.id/assosiasi/hpji/majalah/mjt_0401.pdf (2008)

3. H.T. Tjendani, N. Anwar, I.P.A Wiguna, Eng. J. 9 (2017)

4. P. Pakkala, M. de Jong, J. Aijo, Finnish Road Administration and Next Generation Infrastructure (2007)

5. P. Anastasopoulos, B. McCullouch, K. Gkritza, F. Mannering, K. Sinha, J. Infrastruct. Syst. 16 (2010)

6. Z.Q. Zhu, Y. X. Li, A. Luo, Ind. Eng. Man. 15 (2010)

7. N. Stankevich, N. Qureshi, C. Queiroz, Transport Note TN 27 (2005)

8. G. Liautaud, The World Bank (2004)

9. J.C. Pinero, J.M. de la Garza, Issues related to the assessment of performance based road maintenance contracts (2003)

10. N. Faizal, Konferensi Regional Teknik Jalan ke-12 (2014)

11. Pusat Penelitian dan Pengembangan Jalan dan Jembatan, Dokumen Dukungan Puslitbang Jalan dan Jembatan untuk Implementasi PBC di Direktorat Jendaral Bina Marga (2013).

12. G. Zietlow, http://www.zietlow.com/docs/Using\%20Micro-Enterprises-05.pdf (2005) 
13. G. Lee, Center for Transportation Research Bureau of Engineering Research The University of Texas at Austin (1996)

14. International Road Dynamics, Mainline WIM Sorter System (with Roadside Signing) (1995)

15. J. Sterman, J. Bus. Dyn (2000)

16. Y. Xu, C. Sun, M. Skibniewski, J.F.Y. Chan, H.C. Yeung, H. Cheng, Int. J. Project. Man. 30 (2012) 